\title{
Principle of Rilleture: \\ One of the Leading Ideas \\ in the Works by Azio Corghi
}

\author{
Liudmila V. Gavrilova* \\ Krasnoyarsk State Institute of Art \\ 22 Lenin Str., Krasnoyarsk, 660049, Russia
}

Received 10.10.2015, received in revised form 16.11.2015, accepted 07.01.2016

The works of contemporary Italian composer Azio Corghi is of undoubted interest for the study. His works are performed in the major concert halls in Europe and international festivals, the first nights of his operas took place in the celebrated La Scala in Milan and in other Italian cities, as well as in Germany and Portugal. This paper is aimed at observing a number of musical and theater works from the point of realization in them of one of the leading composer's ideas, namely rethinking of the past in a spirit of modernity. The author uses the notion of rilleture (repeated readings) and finds different ways of this principle realization on the example of A. Corghi's operas and cantatas.

Keywords: Azio Corghi, musical theater, rethinking of the past, rilleture (repeated reading).

DOI: 10.17516/1997-1370-2016-9-1-117-125.

Research area: culture studies.

The history of musical theater is inseparably linked with Italy. For three centuries, this country held a position of superiority in the development of opera. However, in the first half of the $20^{\text {th }}$ century, the situation changed radically. The author would not describe here the causes and characteristics of artistic and stylistic processes of the period, as this issue has already become the object of attention of various researchers. It needs to state only the obvious decline in the opera composing art in Italy during this period ${ }^{1}$.

The revival of interest in the opera genre in Italy began in $1960-70 \mathrm{~s}$. The evidence of this are operas by G.F. Malipiero (1962 - “Don Giovanni”),
L. Nono (1960-61 - "Intoleranza 1960", 197174 - "Al Gran Sole Carico d'Amore", 1984-85 "Prometheus"), L. Berio (1970 - "Opera”, 1982 "La Vera Storia", 1984 - "Un Re in Ascolta", 1998 - "Outis", 1999 - "Cronaca del Luogo"), B. Maderna (1973 - "Satyrikon"), S. Bussotti (1972 - "Lorenzaccio", 1976 - "Nottetempo", 1980 - "Le Racine", 1988 - "Fedra", 1988 "L'Ispirazione”, 1990 - "Bozzetto siciliano").

At the turn of 1980-90s a new composer Azio Corghi (b. 1937) comes to the foreground in this sphere. He belongs, so to speak, to the $4^{\text {th }}$ generation of Italian composers of the $20^{\text {th }}$ century. This generation followed Gian Francesco Malipiero (1882-1973), Ottorino Respighi

(C) Siberian Federal University. All rights reserved

* Corresponding author E-mail address: mgavrilova55@gmail.com 
(1879-1936), Alfredo Casella (1883-1947), who revived the tradition of the Italian instrumental music; Luigi Dallapiccola (1904-1975) and Goffredo Petrassi (1904-2003), who introduced dodecaphony; Luciano Berio (b. 1925), Bruno Maderna (1920-1973) and Luigi Nono (19241990), who represent today the remarkable figures not in Italian art only, but also in the world avantgarde.

One must say that the opera works by Azio Corghi and his music in general are unknown to the Russians ${ }^{2}$. Last year the composer celebrated his $77^{\text {th }}$ birthday, he lives in Milan, where for many years he has headed the Department of Composition at the Conservatory. European recognition to Azio Corghi came after the first night of the opera "Blimunda", first staged in Teatro Lirico in Milan (1989), then in Lisbon (1991) and Turin (1992). The composer received a special award "Premio S.I.A.E. ${ }^{3}$ per Lirica" for this bright and original work. Since that time, the works of A. Corghi have taken a permanent place in the concert halls and theaters across Italy as well as abroad. This very opera also marked the beginning of the unique creative cooperation between the composer and José Saramago, the Portuguese writer and Nobel Laureate in Literature. The libretto for the opera "Blimunda" was written on the basis of J. Saramago's novel "Memorial do Convento" (English title: "Baltasar and Blimunda", 1982), but the acquaintance of the composer and writer took place long before his receiving the Nobel Prize. In 1993, there appeared opera "Divar" (joint work on libretto with J. Saramago by his novel "In the Name of God", 1991), in 1996 - "Isabella", in 1997 "Rinaldo", the latter are versions of operas by G.A. Rossini ("L'Italiana in Algeri”) and G.F. Handel respectively. In 2000 the composer produced a lyrical drama "Tat'jana", on March 7, 2003 Münster saw the first night of a new opera of Chekhov's "Sen'ja" (based on the play
"On the Road"). On March 18, 2006 in Lisbon there was the first night of the opera "Il Dissoluto Assolto" ("Justified libertine"), in autumn the play was shown on the stage of La Scala. In July 2009 Vicenza hosted the first night of the opera "Giocasta" (libretto written by M. MazzokutMies ). Finally, more recently - in early November 2013 in Milan in Teatro dell'Elfo Puccini there was the first night of a lyrical tragedy "Helena" (text by M. Mazzokut-Mies).

It is obvious that A. Corgi is very successful in the opera genre. All his works have been put on the stage. Each of them is an original, distinctive realization of an artistic idea, with semantic multidimensionality of compositional and stylistic devices.

In a short article it is impossible to give a holistic view of this multifaceted world of musical and theater works by Azio Corghi, which, among operas, includes ballets, scenic cantatas, stage actions, performances for children, compositions involving voce recitante, mime and dance. Let us draw attention to just one artistic idea, which has found various realizations in the work of the Milanese composer. Please note that this idea is not a product of purely individual creative personality, but it is rather organically embedded in the context of the major trends in the development of modern art. We cannot but use the statement of the most famous living Italian writer, philosopher and medievalist Umberto Eco found in "Marginal Notes of "The Name of the Rose" (1983) to define this idea:

"Since the past cannot be destroyed, because its destruction leads to dumbness, it must be rethought" (emphasis added) [Eko, 1989, p. 471].

This thesis, which appeared in connection with reflections on modernism and postmodernism, reveals quite clear position of the contemporary artist in relation to the past: the essence is not in the denial of the past, but in its rethinking. It should be noted, however, that the 
Italian researchers of A. Corghi's works do not use the term "rethinking", they rather use a word that in Italian sounds like "revisiting musical traditions". Moreover, the composer himself says that this is not the transcription (!), but a modern approach to musical memory. He "uses the experience of his predecessors and includes it in terms of the new artistic experiment, giving new meaning to them" [Corghi, 2007].

"Complex synthesis... of past and present shows the mechanism of culture, apperceived by modern researchers and defined in the concept of memory" [Lobanova, 1990, p. 42]. Not only U. Eco, who is considered an apologist for postmodernism, but also other noted scientists of our time (including D. Likhachev, Yu. Lotman) emphasize the inseparable connection of modern culture with its memory of the past. It seems to seek to master and absorb all the vast experience of human history.

"My goal, says Krzysztof Penderecki - ... is not moving forward at all accounts, and perhaps as a consequence of that - the destruction of music in general, but the discovery of new sources of inspiration in the past"[Ivashkin, 1983, p. 101]. Azio Corghi emphasizes it as such: "If the music is not a memory, then what is?" [Corghi, 2008].

Let us quote another piece (from personal e-mails sent by Azio Corghi to the author). When asked what explains his constant reference to the past of music culture, the composer replied:

"My constant recurrence, and above all in my works, to a general history of music culture, I think, is the fruit of "love and knowledge": on the one hand, due to my passion for pianoforte (understood as the physical part in the musical event), and on the other hand, due to serious academic education which I got while studying composition.

At the ebb of life G. Verdi used to say: "Study Palestrina and be progressive". However, this does not mean the 'neo-romantic' nostalgia for the past and the need to know the past in order to be able to re-open and re-read the pest 'in the spirit of our time' (also by the means proposed by new electronic technologies)" [Corghi, 2006].

The key phrase in this statement is "to reread the past in the spirit of our time". According to A. Mishchuk, "constant sigh for the past implies the denial of the present and the renouncement of the future, refusal from alternative energy sources, encouraging every society and promoting it forward" [Mishchuk, 2014: 17]. It is no coincidence that Italian musicologist R. Mellache uses the word "rilleture" as the term that defines the specifics of the interaction in Corghi's works of the past in music culture and modernity. The word "rilleture" is translated from Italian as "rereading" or "repeated readings" [Gavrilova, 2006].

I must say that A. Corghi's compositions are capable of revealing the endless possibilities of using rilleture: from editing this or that score of great Italian composers of the past, caused by the need to prepare them for performance, to the sometimes radical reinterpretation of a certain phenomenon in the past of musical culture. Here are some examples.

In the catalog of Casa Ricordi (a publisher of primarily classical music and opera) there is a separate section with A. Corghi's works tribute to A. Vivaldi and G.A. Rossini. They are marked as editorial works (didattiche) and critical reviews (revisione critica). It must be said that this practice is a phenomenon typical of the Italian music. Throughout the $20^{\text {th }}$ century, composers, musicologists and musicians joined their efforts and tried to perform works of Italian composers of the past in public, while much was left to rediscoveries, as, for example, music C.G.A. Monteverdi, A. Vivaldi and others. In this case, the researchers hardly made any changes in the composer's original scores. 
The next level of a kind of creative dialogue with the works of the composer's of the past is works where A. Corghi uses material of some particular works of world classics. Here is just a small list of special Case Ricordi directory:

"Amorsacro/Amorprofano" (1991) - a ballet for soprano, small choir, chamber orchestra and electronics for chamber compositions by G. Verdi.

"Un petit train de plaisir" (1991) - "Small Tourist Train", a ballet for two pianos and percussion by "Pe'ches de vieillesse" ("The Sins of My Old Age") G.A. Rossini.

“...Fero dolore" (1993) - “...Searing (endless) grief" - a dramatic cantata based on C.G.A. Monteverdi's Madonna's Lament and Ariadne's Lament for a female voice, the oboe d'amore, percussion and strings.

"La cetra appesa" (1994) - a cantata based on G. Verdi's popular themes for a soprano, a narrator, a folk choir and an orchestra.

"This is the list" (1996) ("commedia armonica") - "a harmonic comedy" for vocal octet based on Leporello's aria from "Don Giovanni" by W.A. Mozart.

"Isabella" (1996) - a teen-opera based on "L'Italiana in Algeri” by G. Rossini, A. Corghi's scenario by A. Anelli's libretto, for voices (singing and rock), a choir, a rock band, an orchestra and electronic instruments.

"Rinaldo \& C." (1997) - a baroccopera based on "Rinaldo" by G.F. Handel, A Corghi's scenario by A. Hill's libretto, translated by G. Rossi, for voices, a choir (an extended vocal octet) and an orchestra ${ }^{4}$.

"Lalla Rûkh" (2003) by G. Spontini - a theatrical holiday with songs and dances.

What distinguishes the above works is, in our view, following the trend which was approached by L. Berio in his time. Let us recall one of his statements: "I have been willing to undertake a study of musical works of the past. It would be a creative research and at the same time - an analysis, commentary, and a continuation of the original" [Kirillina, 1995, p. 94]. The results of this creative research are shown in the opera "The True Story", which became a kind of paraphrase of G. Verdi's "Il Trovatore".

In our view, A. Corghi develops L. Berio's idea. Operas "Isabella" and "Rinaldo" are modern versions of the scores by G.A. Rossini and G.F. Handel. The changes relate to a greater degree to orchestration (for example, in "Rinaldo" there were added an organ and a harp; "Isabella" was embellished with electronics, rock band music; and both operas widely used the percussions). Other important components are the choir, corrections in vocals, and some rearrangement of several scenes.

In other works from the above list A. Corghi conducted a really creative research in works of the past. A vivid example is the scenic cantata "... fero dolore", the official world first night of which took place on 2 March 2006 in the Italian city of Trento. The name “... fero dolore" (Italian for "... a searing grief") was accompanied by the following text: Cantata drammatica dal Pianto della Madonna sopra il Lamento di Arianna di Claudio Monteverdi, per Voce femminile, Viola, Percussione, Archi (a dramatic cantata based on C.G.A. Monteverdi's Madonna's Lament and Ariadne's Lament for a female voice, the oboe d'amore, percussion and strings). This composition indicates that in the framework of one work A. Corghi combined two different themes - ancient, mythological one (suffering of Ariadne, a daughter of King Minos of Crete, abandoned by Theseus) and the medieval, Christian one (suffering of the Virgin Mary, who lost her son). However, both parts were to be sung by a single female singer - mezzo-soprano. The only difference is that Ariadne sings in Italian, and Mary sings in Latin. The soloist must constantly switch from one role to another. 
Nevertheless, it happens quite naturally, aided by the fact that the heroines( suffering Ariadne, abandoned by her lover, and crying Maria, who lost her son) experience quite the same emotional state and have consolidated system of feelings and thoughts 5 .

The vocal parts use a citation - a famous "Lamento Arianna" by C.G.A. Monteverdi. Moreover, "Lamento" is reproduced throughout the entire composition, like cantus firmus. As for the orchestral accompaniment, it is a product of the modern type of musical thinking, in spite of the obvious relationship of a number of elements with the part of basso continuo.

Specifics of "riletture", if we will use R. Mellache's term, can be formulated as follows: "While belcanto keeps seducente riconoscibilita (like diplomatic immunity) in life citation, timbre and instrumental context in which belcanto plunges, creates intrigue in reality" [Corghi, 2010]. One of the materials that characterize the peculiarities in A. Corghi's music uses the physical notion - diffraction (literally meaning "breaking into pieces, inflexion of obstacles by sound waves"). If one applies this term to describe a method of "riletture", the citation is actually subjected to diffraction, while C.G.A. Monteverdi vocal lines remain intact. At the same time, all the instrumental sound material, "inflecting around vocal lines", creates "an intrigue in reality" [Corghi, 2010].

We find a similar technique in the opera "Tat'jana", which premiered on the stage of La Scala in 2000 , directed by P. Stein. Since the action takes place against the background of a wedding ceremony in the Russian church, the composer of the score included in his work fragments of the Liturgy of St. John Chrysostom by P.I. Tchaikovsky.

Using the church music of the Russian composer in the Italian version of A.P. Chekhov's play is not objectionable as well. To the best of our knowledge, there is no author music for the text of the wedding ceremony. Therefore the appeal to the liturgical music created for the traditional rite of the Orthodox Church is understandable. Moreover, in certain components the rite of wedding service and I. Chrysostom's liturgy are alike: in litany (prayer petitions) with acclamations of "Lord, have mercy on us", "Lord, give us", "Amen", the extracts from the Epistle and the Gospels, the inclusion of the prayer "Our Father" ("Pater Noster"). It is essential that the composer never violates the semantic boundaries of correspondences between the wedding ceremony, which is a key component of the action and accompanying it fragments of music written by P.I. Tchaikovsky. Fragments from Liturgy are to likened cantus firmus in the composition. The main techniques for working with P.I. Tchaikovsky's musical material is citation: somewhere accurate, but in some cases there were little textural and rhythmic changes in pitch movement or in combining some individual phrases. Almost all the time the choral singing is superimposed by sound of the orchestra, in the first two scenes there is primarily a group of percussion instruments, from the third one strings and piano dominate.

The author must say that working with "foreign word" is a typical technique for the Italian composer's creative method; quoted material in his works coexist with the author's one in a very organic manner. The composer actively involves in stylistic space of his music a variety of multifaceted musical phenomena. In this respect the composer is literally integrated into one of the leading trends of his time. To paraphrase S. Averintsev, we can say that the citation in the $20^{\text {th }}$ century became "an obsession" [Averintsev, 1969: 171] in music (more widely - in other arts) in the second half of the century.

There is an article devoted to a variety of A. Corghi's techniques involving work with 
citations [Gavrilova, 2009]. Here we shall attract attention to another enough original manifestation of rilleture in the work of the composer: the creation of new versions of various subjects belonging to the treasury of world culture, what L. Berio described as "a continuation of the original".

Some striking examples of this work with citations are the scenic cantata "The Death of Lazarus" and the opera "Il Dissoluto Assolto". Libretto for both works was created together with J. Saramago.

The cantata uses the story of Lazarus as told in J. Saramago's novel "The Gospel According to Jesus Christ". The writer and then the composer offer their own version of events different from the canonical one.

Let us recall what John the Evangelist writes when Jesus saw the weeping Mary he himself, "groaned in the spirit, and was troubled" (John 11:33, cited hereinafter for the purpose of the present study by American Standard Version). On his order the cave - the burial place of the deceased was opened. Jesus "he cried with a loud voice, Lazarus, come forth. He that was dead came forth, bound hand and foot with graveclothes; and his face was bound about with a napkin. Jesus saith unto them, Loose him, and let him go" (John 11: 43-44).

Compare the foregoing episode with J. Saramago's version of "The Gospel According to Jesus Christ": "Lazarus would rise, because God wanted so, but at the last minute - really last and ultimate - Mary Magdalene put her hand on his shoulder and said these words: "No one on earth has sinned so hard to die twice ... and Jesus came and dropped his hands, weeping" [Saramago, 2006, pp. 426-427].

In J. Saramago and A. Corghi's works Jesus does not resurrect Lazarus!

Even more curious is the new version of W.A. Mozart "Don Giovanni”, which, as you know, is called "Il Dissoluto Punito, ossia Il Don Giovanni" ("Punished Libertine, or Don Juan"). A. Corghi and J. Saramago's opera is called "Il Dissoluto Assolto" ("Justified Libertine").

The first scene of the opera is an analogue of the final scene of W.A. Mozart's opera Don Giovanni is sitting at the table, looking through the catalog and making the last records in it. A knock on the door, it opens and he sees a statue standing on the threshold... However, further events are evolved in the direction opposite to Da Ponte's libretto: Don Giovanni deliberately mocks Commander, while the statue's efforts to burn the libertine in fire end in a fiasco.

Here are the lines from the J. Saramago's letter, written at the very beginning of work on the libretto:

"The fact that these characters were participants in Lorenzo da Ponte's final scene from would have obliged us to use again (alas, at a very low level) the conviction and the fall of Don Giovanni into Hell.

My idea is a little more complicated. There will be a "choir" (but in a "cut" version), Donna Anna, Donna Elvira, Don Ottavio and Masetto. In addition, Commander and Leporello. What do they want? The only way to "beat" Don Giovanni is to deny his amorous conquests in spite of their truth, like: Don Giovanni is a liar, he has not seduced a single woman in all his life. And when poor Don Giovanni, trying to protect and defend himself, orders Leporello to show a remarkable catalog, we see that all its sheets are white (clean)... That's the way our Don Juan would be defeated, humiliated, despised Giovanni. Sarcasm would fall on him with all its weight, and the sensible ones would triumph" [Corghi, 2009].

This seems to be a manifestation of one of the most interesting developments of the last century, which is deglorification, deheroization of artistic idols of the previous eras: "the humanity as if leaves, laughing its ... past, offering a series of 
"reduced and deheroized to vulgarization figures of Faust and Mephistopheles" [Iakusheva, 1999: 31]. One can certainly add Don Giovanni to this line; he is the only one legendary hero in the whole history of the world culture, not borrowed by the theater, but rather created by the theater.

The idea of creating sequels for the wellknown artistic creations of the past was realized in the opera "Jocasta". It was created for performances in Teatro Olimpico in Vicenza as a part of the celebration of the $500^{\text {th }}$ anniversary of A. Palladio. For the opening of the theater in 1585 there was staged Sophocles' "Oedipus the King”, with music by A. Gabrieli. A. Corghi and M. Mazzokut-Mis (author of the libretto) opera offers a modern version of the continuation of a great tragedy. Jocasta, Queen of Thebes, meets her blind and imprisoned son-spouse Oedipus. Overcoming the terror, she tells him about her life, full of wandering and suffering. The curse also hit their sons (Eteocles and Polynices), who killed each other, and also Oedipus' daughter Antigone, who sacrificed herself to bury one of her brothers. Jocasta as a mother forgives Oedipus and also justifies herself in front of him.
"I'm telling you this not to hurt and trouble you, this is the mother's pity hidden in her story confession". After Oedipus, who by this time had become powerless and like a child, started crying, Jocasta took his hand and became his eyes.

I think that the fact that the play "Tat'jana" (almost unknown in Russia) at the time was written by A.P. Chekhov as a continuation of A. Suvorin's play "Tatyana Repina" (1889) became crucial for A. Corghi, when he agreed to work with P. Stein to create an opera for La Scala.

Undoubtedly, the works of the Italian composer Azio Corghi for the musical theater produce rich material for the study of the most significant trends in contemporary art. His developments are naturally embedded in the artistic and stylistic processes relevant to many phenomena today. Like many others, he is looking for his own way of establishing a dialogue with the artistic past of the world culture. The principle of rilleture (repeated readings) set in his works opens up endless possibilities for the realization of the leading in his works artistic idea, which is a rethinking of the past in a spirit of modernity

1 A possible exception are the works by L. Dallapiccola, created in the 1940s. - "Night Flight" (1940), "The Prisoner" (19441948), “Job” (1950).

2 There were only two performances of his cantata “... fero dolore": in 2005 in Krasnoyarsk, and in 2010 - in St. Petersburg.

The abbreviation standing for Italian Society of Authors and Publishers, founded in 1882.

4 Opera "Isabella" was staged in Pesaro in 1998, "Rinaldo" was staged at The Teatro Massimo Bellini in Catania in 1997. This seems to be yet another manifestation of the feature characteristic of the modern artistic practice, which the researchers of postmodernism define as "simultaneity of events occurring at different times".

\section{References}

Averintsev S. (1969). Kul'turologiia I. Heizingi [J. Huizinga's Culturology]. Voprosy filosofii (Issues of Philosophy), (3), pp. 169-174.

Corghi A. Pis'mo A. Corghi L.Gavrilovoi ot 24.05.2007-materialy iz lichnoi elektronnoi perepiski [Letter from A. Corghi to L.Gavrilova of 24.05.2007 - material from personal e-mails]. 2007.

Corghi A. Pis'mo A. Corghi L. Gavrilovoi ot 15.03.2009 - materialy iz lichnoi elektronnoi perepiski [Letter from A. Corghi to L.Gavrilova of 15.03.2009 - material from personal e-mails]. 2009.

Corghi A. Pis'mo A. Corghi L. Gavrilovoi ot 24.06.2010- materialy iz lichnoi elektronnoi perepiski [Letter from A. Corghi to L.Gavrilova of 24.06.2010 - material from personal e-mails].2010. 
Corghi A. Pis'mo A. Corghi L. Gavrilovoi ot 4.03.2008-materialy iz lichnoi elektronnoi perepiski [Letter from A. Corghi to L.Gavrilova of 4.03.2008 - material from personal e-mails]. 2008.

Corghi A. Pis'mo A. Corghi L. Gavrilovoi ot 7.11.2006-materialy iz lichnoi elektronnoi perepiski [Letter from A. Corghi to L.Gavrilova of 7.11.2006 - material from personal e-mails]. 2006.

Eko U. Imia rozy [The Name of the Rose]. Moscow, 1989. 488p.

Gavrilova L. Printsip rilleture v tvorchestve Atsio Corghi [Principle of rilleture in the works of Azio Corghi]. Kritika. Publitsistika. Stranitsy istorii. K XXX-letiiu kafedry muzykal'noi kritiki (Criticism. Publicism. Pages of history. By the $30^{\text {th }}$ Anniversary of the Department of Musical Criticism). SaintPetersburg, 2006, p.53-66.

Gavrilova L. Semanticheskie grani tsitaty v tvorchestve Atsio Corghi [Semantic aspects of citations in the works by Azio Corghi]. Semiotika khudozhestvennoi kul'tury: Obraz Rossii v mezhkul'turnoi kommunikatsii: materialy Mezhdunarodnoi nauch.-pr. konferentsii (Semiotics in artistic culture: The image of Russia in intercultural communication: materials of the International Scientific and Practical Conference). Kemerovo-Saint-Petersburg, 2009, pp. 160-172.

Iakusheva G. (1999). Degeroizirovannyi Faust XX veka [Deheroized Faust of the $20^{\text {th }}$ century]. Getevskie chteniia (Goethe's readings). Moscow, pp.31-49.

Ivashkin A. Kshishtof Penderetskii [Krzysztof Penderecki]. Moscow, 1983. 102 p.

Kirillina L. Liuchano Berio [Luciano Berio]. XX vek. Zarubezhnaia muzyka (The $20^{\text {th }}$ century. Foreign Music). Moscow, 1995, pp.74-109.

Lobanova M. Muzikal'nyi stil' i zhanr: istoriia i sovremennost' (Musical style and genre: Past and Present). Moscow, 1990. 224 p.

Mishchuk A. (2014). Kul'turnaia tsennost' sovremennogo iskusstva [Cultural value of modern art]. Voprosy kulturologii (Issues of Culturology), (4), pp.14-18.

Saramago J. Evangelie ot Iisusa [The Gospel of Jesus]. Moscow, 2006. 448 p. 


\title{
Принцип rilleture: одна из ведущих идей
}

\section{в творчестве Ацио Корги}

Л.В. Гаврилова

Красноярский государственный институт искусств

Россия, 660049, Красноярск, Ленина, 22

\begin{abstract}
Творчество современного итальянского композитора Аџио Корги представляет несомненный интерес для исследования. Его сочинения исполняются на крупных кониертных площадках Европы и международных фестивалях, оперные премьеры состоялись на сиене знаменитого Миланского театра Ла Скала, других городов Италии, а также в Германии и Португалии. В данной статье рассматриваются целый ряд музыкально-театральных сочинений с точки зрения реализации в них одной из ведущих художественных идей в творчестве композитора переосмысление прошлого в духе современности. Автор использует понятие rilleture (повторные чтения) и обнаруживает различные способы претворения данного принципа на примере опер и сиенических кантат А. Корги.
\end{abstract}

Ключевые слова: Аиио Корги, музыкальный театр, переосмысление прошлого, rilleture (повторные чтения).

Научная специальность: 24.00.00 - культурология. 